\title{
Indirect Determination of Chlorpromazine Hydrochloride by Square Wave Voltammetry of Sodium Nitroprusside: Application to Pharmaceutical Formulations
}

\author{
Anfal R. Mahmood \\ Department of Chemistry \\ College of Science \\ University of Mosul
}

(Received 11/6/2012;Accepted 8/10/2012)

\begin{abstract}
An indirect voltammetric method was developed for the determination of chlorpromazine hydrochloride (CPZ) via square wave voltammetric behavior of sodium nitroprusside (SNP) which gives a well-defined square wave voltammetric peak at $(-0.589) \mathrm{V}$ against the reference electrode $(\mathrm{Ag} / \mathrm{AgCl} / \mathrm{Sat} \mathrm{KCl})$. The addition of $\mathrm{CPZ}$ leads to the decrease of the reduction peak of SNP due to the interaction of SNP with CPZ. The decrease in the peak current $\left(\Delta \mathrm{I}_{\mathrm{p}}\right)$ was found to be linear and related to the concentration of $\mathrm{CPZ}$ within the range of concentration $\left[\left(0.490 \times 10^{-6}\right)-\left(9.77 \times 10^{-6}\right)\right] \mathrm{M}$ with a correlation coefficient of (0.9948). The method had been successfully applied to determine the CPZ in a pure form and in pharmaceutical formulations.
\end{abstract}

Keywords: Chlorpromazine hydrochloride; Sodium nitroprusside; Square wave voltammetry.

\section{القحير غير المباشر الكلوريومازن بولمطة فولتامتري الموجة المرهة لنيتروروسيد الصويوه: قلبق الارقة علل المستحضرات الصيدلنية \\ الماخص}

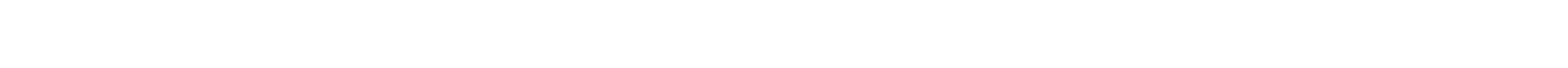

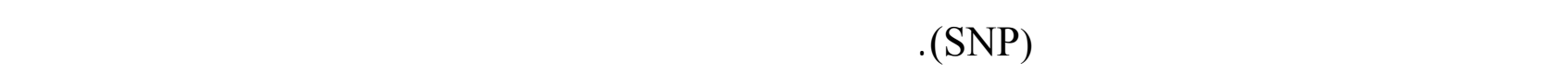

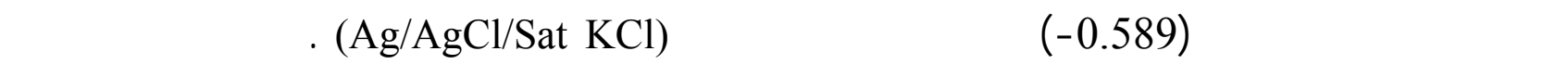

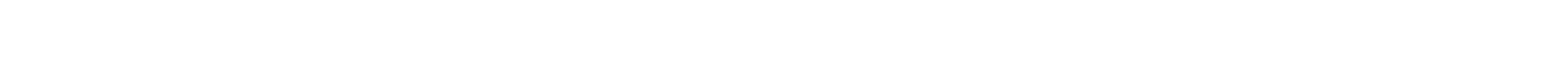

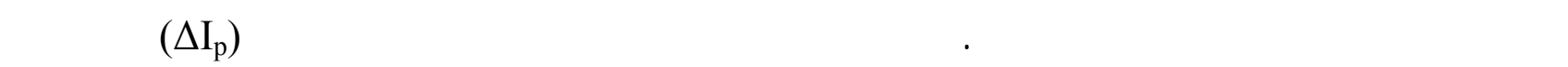

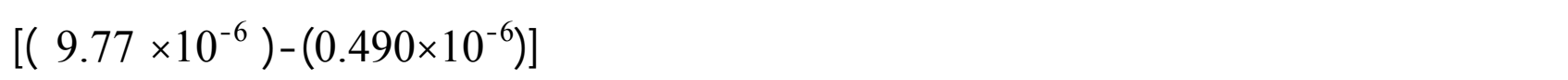

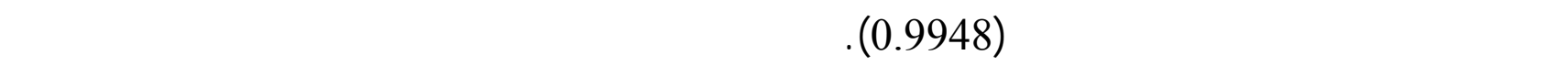
بشكله الحر وفي مستحضرالته الصيدلانية. الكاملت الدالة: الكلوربرومازين، نيتروبروسيد الصوديوه، فولتلمتري الموجة المربعة. 


\section{INTRODUCTION}

Sodium nitroprusside is an inorganic compound with the formula $\mathrm{Na}_{2}\left[\mathrm{Fe}(\mathrm{CN})_{5} \mathrm{NO}\right]$. $2 \mathrm{H}_{2} \mathrm{O}$. This red coloured salt, which is often abbreviated as SNP, is a potent vasodilator. This sodium salt is soluble in water and to a lesser extent in ethanol to give solutions containing the dianion $\left[\mathrm{Fe}(\mathrm{CN})_{5} \mathrm{NO}\right]^{2-}$ (Butler and Megson, 2002).

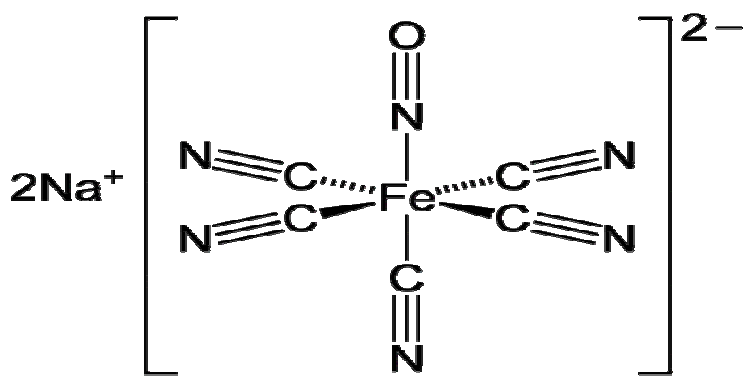

Fig. 1: The chemical structure of sodium nitroprusside, $M . w t .=298 \mathrm{~g} / \mathrm{mole}$.

Chlorpromazine hydrochloride (CPZ), has the IUPAC name [3-(2-chloro-10Hphenothiazine-9-yl)-N,N_dimethyl-propan-1-amine] as shown in Fig. (2) (Healy, 2004).

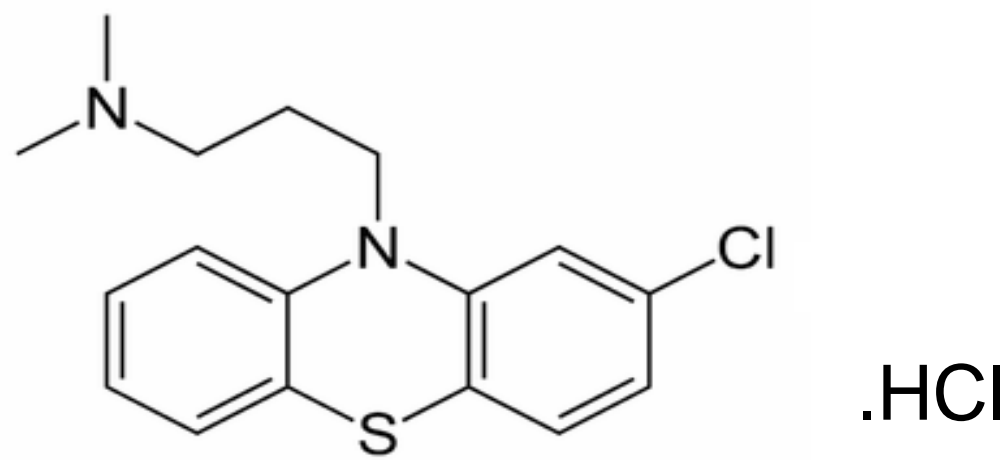

Fig. 2: The structural formula of Chlorpromazine hydrochloride, M.wt. $=355.33$ g/mole.

CPZ is a typical antipsychotic and it was synthesized in 1950. CPZ was the first drug developed with specific antipsychotic action, and would serve as the prototype for the phenothiazine class of drugs, which later grow to comprise several other agents.

CPZ works on a variety of receptors in the central nervous system, producing anticholinergic, antidopaminergic, antihistaminic, and weak antiadrenergic effects. (Diaz, 1997).

Several methods have been described for the determination of CPZ including highperformance liquid chromatography procedures coupled with different types of detectors [fluorescence (Butterfield et al., 1980), ultraviolet (Stevenson and Reid, 1981), (Rukadze et al., 1999) and electrochemical detection (Murakami et al.,1982)].

A novel spectrophotometric method has been established to determine CPZ using potassium ferricyanide. The method has been successfully applied to determine CPZ in pharmaceutical and serum samples (Li-tao et al., 2011).

CPZ was also determined by a spectrophotometric method which is based on the oxidative coupling ability of 3-methylbenzothiazolinone-2-hydrazone [MBTH] with the 
drug in presence of $\mathrm{FeCl}_{3}$ under acidic condition. The proposed method has been successfully applied to routine pharmaceutical analysis of the sited drug (Vijay Raju et al., 2011).

An original, simple and sensitive flow-injection spectroelectoranalytical method has been described for the determination of $\mathrm{CPZ}$ in a pure form or in pharmaceutical formulations (Daniel and Gutz, 2005).

The electrochemical behaviour of $\mathrm{CPZ}$ in sulphuric acid was investigated voltammetrically using rethenium electrodes and it was subsequently determined by the same method. The proposed voltammetric method was applied to the determination of CPZ in tablets (Dermis and Biryol, 1989).

CPZ and promethazine were also determined by differential pulse stripping voltammetry using glassy carbon electrode in Britton-Robinson buffer of $\mathrm{pH}=9$. The proposed method was applied to determine these two drugs in a set of synthetic mixtures and blood samples (Ni et al., 2001).

Carbon paste electrode has been developed for the potentiometric determination of CPZ Drug focused on the fabrication of carbon paste ion selective electrode for determination of the drug under investigation using potentiometric titration with sodium tetra phenyl borate (Frag et al., 2012).

The present work involves an indirect method for determination of CPZ through the square wave voltammetric behavior of SNP.

\section{Apparatus}

\section{EXPERIMENTAL}

Voltammetric measurements were carried out using a metrohm instrument, model 797 VA, computerized with stand three - electrodes containing an HMDE as a working electrode, an $(\mathrm{Ag} / \mathrm{AgCl}-\mathrm{Sat} \mathrm{KCl})$ as reference electrode and a platinum wire as an auxiliary electrode. The $\mathrm{pH}$ of the solutions was controlled with a (HANA) $\mathrm{pH}$ meter.

\section{Reagents}

All of the chemicals used were of analytical-reagent grade. The supporting electrolyte used for all experiments was phosphate buffer which was prepared by mixing certain volumes of (0.2) $\mathrm{M}$ of each of $\mathrm{K}_{2} \mathrm{HPO}_{4}$ and $\mathrm{KH}_{2} \mathrm{PO}_{4}$.

A Sodium nitroprusside solution $\left(1.0 \times \mathbf{1 0}^{-3} \mathbf{M}\right)$ was freshly prepared by dissolving (0.00298) g SNP (Fluka) and the volume was completed to $10 \mathrm{ml}$ in a volummetric flask.

A Chlorpromazine hydrochloride solution $\left(1.0 \times 10^{-3} \mathrm{M}\right)$ was freshly prepared by dissolving (0.00355) g CPZ (NDI-Iraq) in distilled water and the volume was completed to $10 \mathrm{ml}$ in a volummetric flask.

\section{Chlorpromazine hydrochloride tablet solution}

The tablet was obtained from (SDI). Ten tablets of CPZ labelled with amount of (50) mg per tablet were completely grounded and homogenized. (0.02414) $\mathrm{g}$ of the powder was accurately weighed and dissolved in $10 \mathrm{ml}$ of distilled water. After the mixing was completed, the mixture was filtered with an ordinary filter paper and the clear filtrate was used for the determination. 


\section{Procedure}

The square wave voltamogram was recorded for the sample using a cell containing (10)ml of phosphate buffer at $\mathrm{pH}=7.0$ at optimum conditions [Table 1] to obtain the blank current. Then $150 \mathrm{ml}$ of $\left(14.77 \times 10^{-6}\right) \mathrm{M}$ of SNP was added and the voltamogram was then recorded to give the Ip of SNP, then an appropriate amount of $\left(10^{-4}\right) \mathrm{M}$ of CPZ was added to the cell and the voltamogram was recorded to determine the $\mathrm{CPZ}$ in pure and in tablets.

\section{RESULTS AND DISCUSSION}

Typical square wave voltamogram of $\left(9.9 \times 10^{-6}\right)$ M SNP in phosphate buffer at $\mathrm{pH}=7.0$ is shown in Fig. 3.

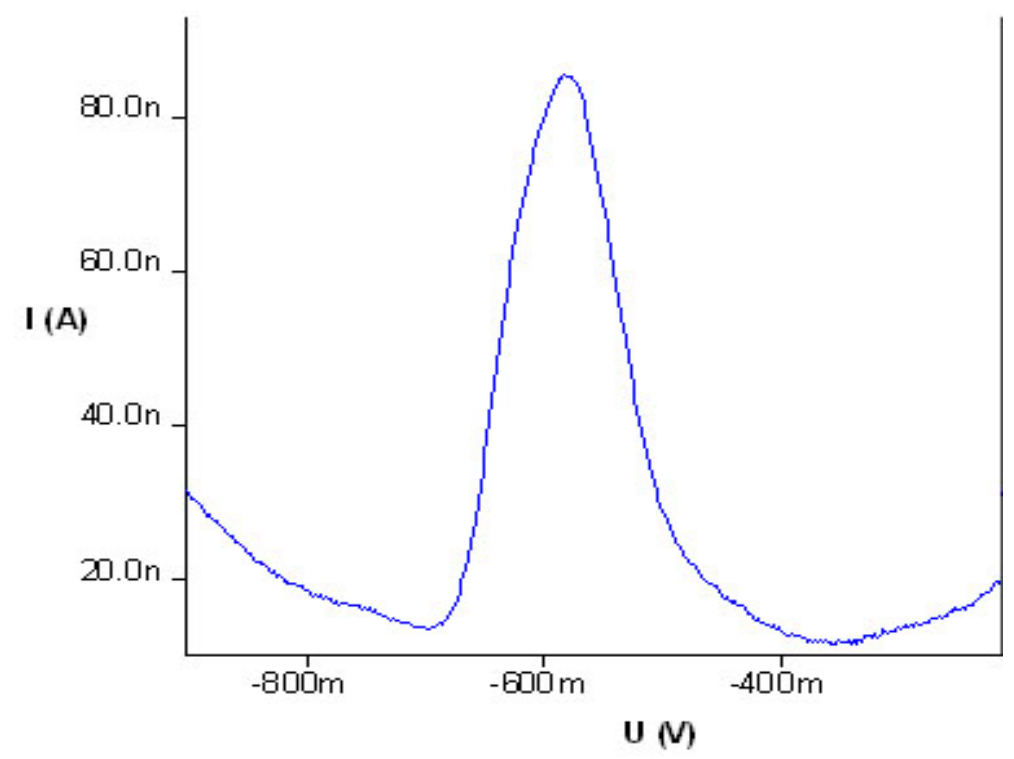

Fig. 3: Square wave voltamogram of $\left(9.9 \times 10^{-6}\right) M$ SNP at $(\mathrm{pH}=7.0)$

It can be seen from Fig. 3, that SNP showed a well-defined peak which is appeared at $(-0.589) \mathrm{V}$ versus $(\mathrm{Ag} / \mathrm{AgCl}$, Sat $\mathrm{KCl})$ electrode.

\section{Optimum Conditions}

The square wave voltamogram of $\left(9.9 \times 10^{-6}\right) \mathrm{M}$ of SNP was investigated in phosphate buffer $(\mathrm{pH}=7.0)$ by variation of all the parameters of the measurements, the optimum values obtained are tabulated in Table (1).

Table 1: The optimum values obtained which give either the highest peak current or the best resolution of the peak

\begin{tabular}{|c|c|c|c|}
\hline Condition & Value & Condition & value \\
\hline Initial pot. & $-0.1 \mathrm{~V}$ & Frequency & $50 \mathrm{~Hz}$ \\
\hline Final pot. & $-0.9 \mathrm{~V}$ & Equilibration time & $50 \mathrm{~s}$ \\
\hline Voltage step & $0.002 \mathrm{~V}$ & Deposition time & $60 \mathrm{~s}$ \\
\hline Amplitude & $0.04 \mathrm{~V}$ & $\begin{array}{c}\text { Deposition } \\
\text { potential }\end{array}$ & $-0.9 \mathrm{~V}$ \\
\hline
\end{tabular}




\section{Effects of pH}

The square wave voltamogram of $\left(14.77 \times 10^{-6}\right) \mathrm{M}$ of SNP was investigated at different $\mathrm{pH}$ values $(3-9)$ using the optimum conditions (Table 1) in phosphate buffer. The peak current (Ip) and the peak potential (Ep) obtained are shown in (Table 2).

Table 2: Effect of $\mathrm{pH}$ on SWV peak potential and peak current of $\left(14.77 \times 10^{-6}\right) \mathrm{M}$ of SNP

\begin{tabular}{|c|c|c|}
\hline $\mathbf{p H}$ & $\mathbf{E p ~ ( V )}$ & $\mathbf{I p ( n A )}$ \\
\hline 3 & -0.370 & 53.9 \\
\hline 5 & -0.470 & 128.5 \\
\hline 7 & -0.591 & 140.5 \\
\hline 9 & -0.701 & 110.44 \\
\hline
\end{tabular}

The peak current (Ip) is clearly dependent on $\mathrm{pH}$. A maximum current response was found at $(\mathrm{pH}=7.0)$. On the other hand, the peak potential $(\mathrm{Ep})$ is found to be greatly dependent on $\mathrm{pH}$ and moves to more negative values with increasing the $\mathrm{pH}$ values. Linear plot of Ep versus $\mathrm{pH}$ was obtained in (Fig. 4) with a slope $(-0.0560) \mathrm{V} / \mathrm{pH}$ and $(\mathrm{R}=0.9988)$ which is very near to the theoretical value obtained by Hammett $(0.059) \mathrm{V} / \mathrm{pH}$ (Hammett, 1940).

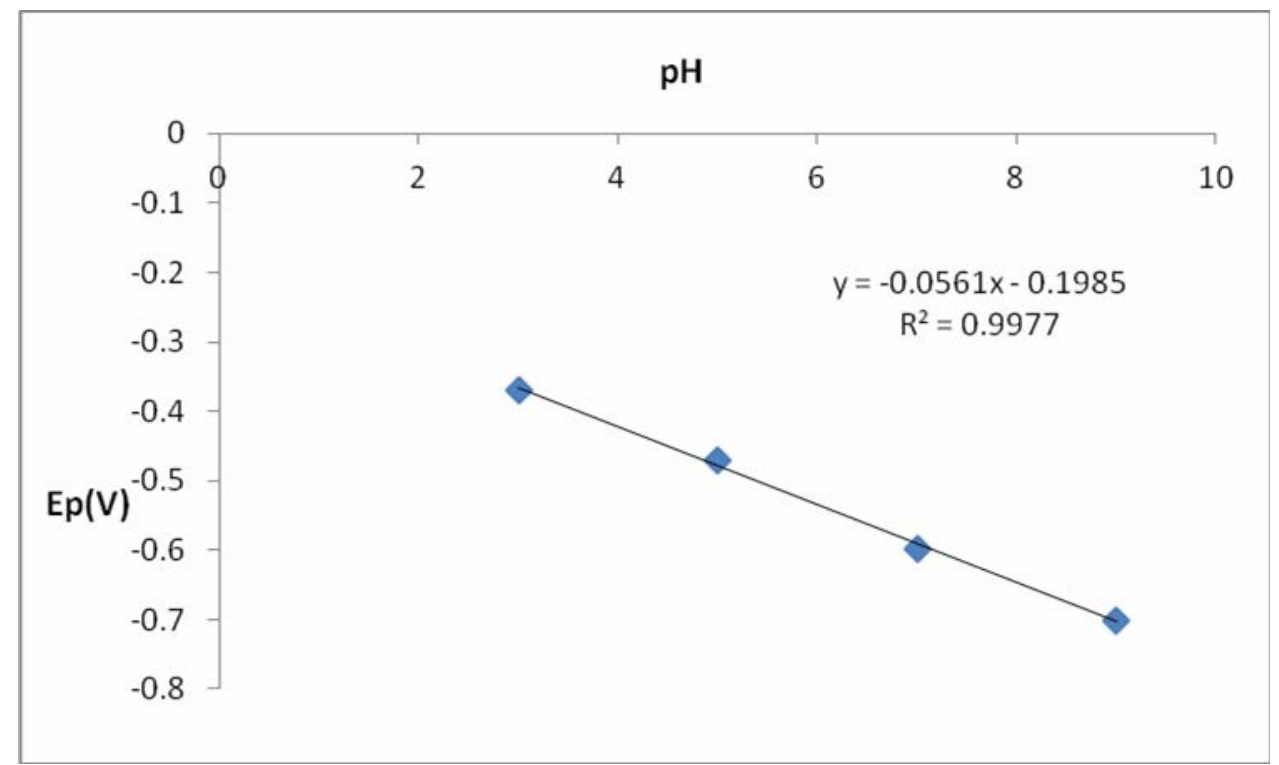

Fig. 4: The relation between Ep and $\mathrm{pH}$ of $\left(14.77 \times 10^{-6}\right) \mathrm{M}$ of SNP

\section{Stability of SNP in aqueous phosphate buffer at (pH 7.0)}

The square wave voltamogram of $\left(14.77 \times 10^{-6}\right) \mathrm{M}$ of SNP was recorded at different times in phosphate buffer at $(\mathrm{pH}=7)$. The results obtained are tabulated in (Table 3). 
Table 3: Effect of time on SWV peak of $\left(14.77 \times 10^{-6}\right)$ of $\mathrm{SNP}$ at $\mathrm{pH}=7.0$ in aqueous solution

\begin{tabular}{|c|c|}
\hline Time (min) & Ip (nA) \\
\hline 5 & 163 \\
\hline 10 & 159 \\
\hline 15 & 134 \\
\hline 20 & 157 \\
\hline 25 & 142 \\
\hline 30 & 144 \\
\hline 35 & 143 \\
\hline 40 & 157 \\
\hline 45 & 150 \\
\hline 50 & 150 \\
\hline 55 & 151 \\
\hline 60 & 157 \\
\hline
\end{tabular}

It can be seen from (Table 3) that SNP is stable for 60 minutes.

\section{Analytical considerations}

Using the optimum conditions shown in (Table 1), the calibration curve was constructed using a serial dilution of the standard SNP $\left(10^{-3}\right) \mathrm{M}$ in aqueous - phosphate buffer $(\mathrm{pH}=7.0)(10 \mathrm{ml})$. The results are listed in (Table 4).

Table 4:The effect of concentration on the peak current of $\left(0.99 \times 10^{-6}\right)-\left(38.46 \times 10^{-6}\right) \mathrm{M}$ of $\mathrm{SNP}$ at $(\mathrm{pH}=7.0)$ in aqueous solution at $\mathrm{Ep}=-0.591 \mathrm{~V}$

\begin{tabular}{|c|c|}
\hline Conc. $(\mathbf{M}), \times \mathbf{1 0}^{-\mathbf{6}}$ & Ip (nA) \\
\hline 0.999 & 14 \\
\hline 1.990 & 28 \\
\hline 2.991 & 41 \\
\hline 3.980 & 55.8 \\
\hline 4.975 & 70.5 \\
\hline 5.964 & 86.2 \\
\hline 6.951 & 103 \\
\hline 7.936 & 115 \\
\hline 8.919 & 130 \\
\hline 9.900 & 144 \\
\hline 14.778 & 183 \\
\hline 19.608 & 199 \\
\hline 24.390 & 221 \\
\hline 33.126 & 240 \\
\hline 38.462 & 268 \\
\hline & 288 \\
\hline
\end{tabular}




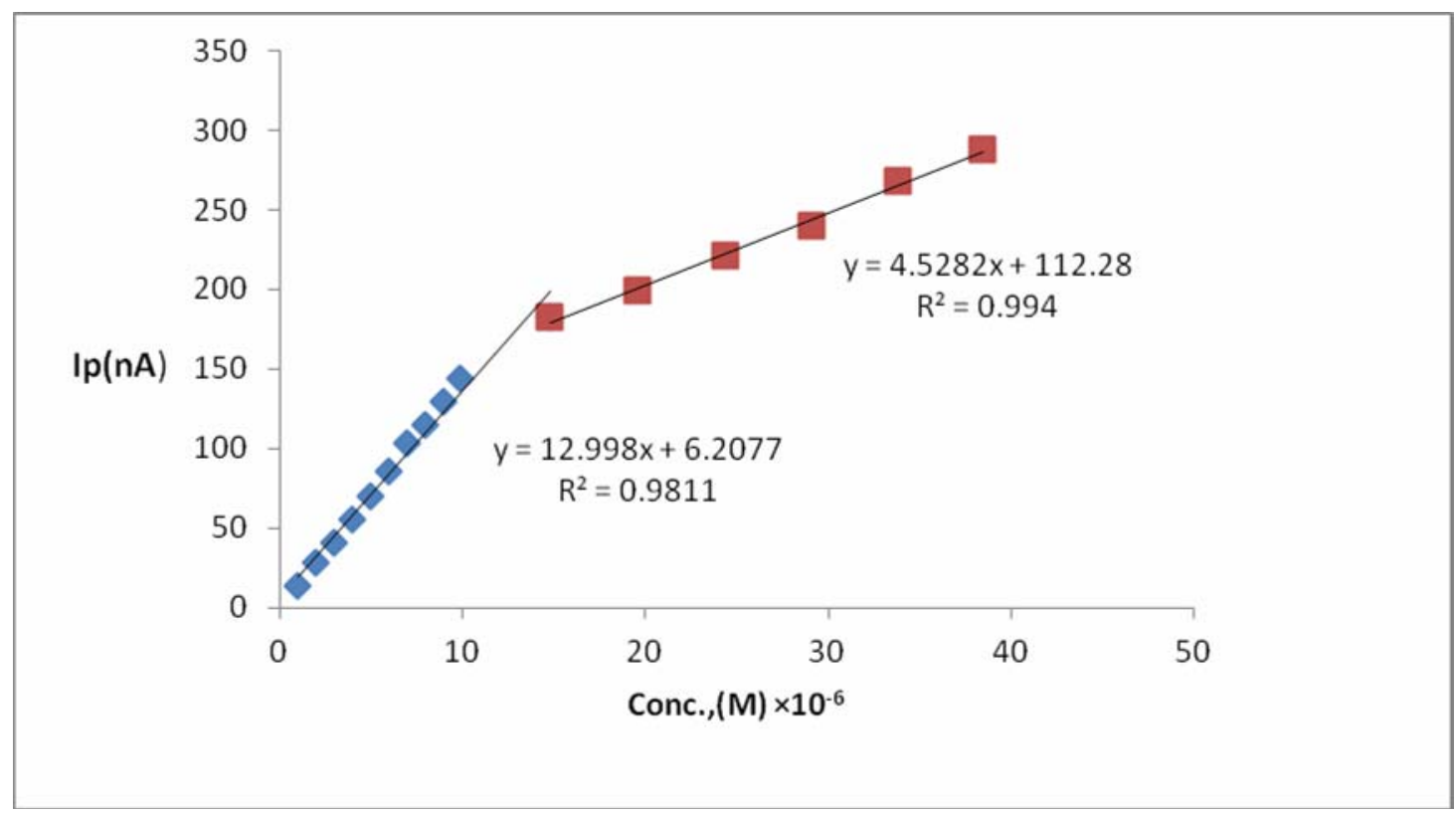

Fig. 5: The relation between peak current (Ip) and concentration of $\mathrm{SNP}$ at $(\mathrm{pH}=7.0)$ in phosphate buffer

The plot of peak current Ip versus molar concentration of SNP is shown in Fig.(5). Regression analysis on standard SNP indicated two straight lines, the first one with a concentration range of $\left[\left(0.99 \times 10^{-6}\right)-\left(14.77 \times 10^{-6}\right)\right] \mathrm{M}$, with a correlation coefficient of $(\mathrm{R}=0.9905)$. The second with the concentration range $\left[\left(14.77 \times 10^{-6}\right)-\left(38.462 \times 10^{-6}\right)\right] \mathrm{M}$ with correlation coefficient of $(\mathrm{R}=0.9970)$. This behavior may be due to the change of the rate of diffusion with concentration and increased gradually by increasing concentration. It is wellknown that the rate of reduction depends mainly on the rate of diffusion (Willard et al., 1974). The lowest experimental determination limit was $\left(0.99 \times 10^{-6}\right) \mathrm{M}$.

\section{The calibration curve of CPZ in the presence of SNP}

The square wave voltamogram of $\left(14.77 \times 10^{-6}\right) \mathrm{M}$ of SNP in phosphate buffer at $(\mathrm{pH}=7.0)$ was recorded, successive amounts of $\mathrm{CPZ}$ were then added and the $\mathrm{SW}$ voltamogram was recorded after each addition. The results are shown in (Table 5). The peak current Ip of SNP was found to be decreased gradually with the addition of CPZ. This behavior is due to the interaction of SNP with CPZ. The plot of $\left(\Delta \mathrm{I}_{\text {pcorr. }}\right)$ versus concentration of the CPZ added is shown in (Fig. 6), where the $\mathrm{Ip}_{\mathrm{o}}=156 \mathrm{nA}$ represents the peak current of SNP only. 
Table 5: The peak current of CPZ $\left(0.490 \times 10^{-6}\right)-\left(9.777 \times 10^{-6}\right)$ in the presence of $\left(14.77 \times 10^{-6}\right) \mathrm{M}$ of $\mathrm{SNP}$ in phosphate buffer $(\mathrm{pH}=7.0)$

\begin{tabular}{|c|c|c|}
\hline Conc. $\mathbf{( M )}, \times \mathbf{1 0}^{-\mathbf{6}}$ & $\mathbf{I}_{\mathbf{p}} \mathbf{( n A )}$ & $\boldsymbol{\Delta I}_{\mathbf{p c o r r}} \mathbf{( n A )}$ \\
\hline 0.490 & 154 & 15.38 \\
\hline 0.975 & 153 & 16.38 \\
\hline 1.456 & 147 & 22.38 \\
\hline 1.932 & 141 & 28.38 \\
\hline 2.403 & 138 & 31.38 \\
\hline 2.870 & 133 & 36.38 \\
\hline 3.791 & 121 & 48.38 \\
\hline 4.694 & 103.6 & 65.78 \\
\hline 5.581 & 84.4 & 84.98 \\
\hline 6.451 & 69.3 & 100.08 \\
\hline 7.305 & 55.1 & 114.28 \\
\hline 8.144 & 46.8 & 122.88 \\
\hline 8.968 & 35.5 & 133.88 \\
\hline 9.777 & 28.6 & 140.78 \\
\hline
\end{tabular}

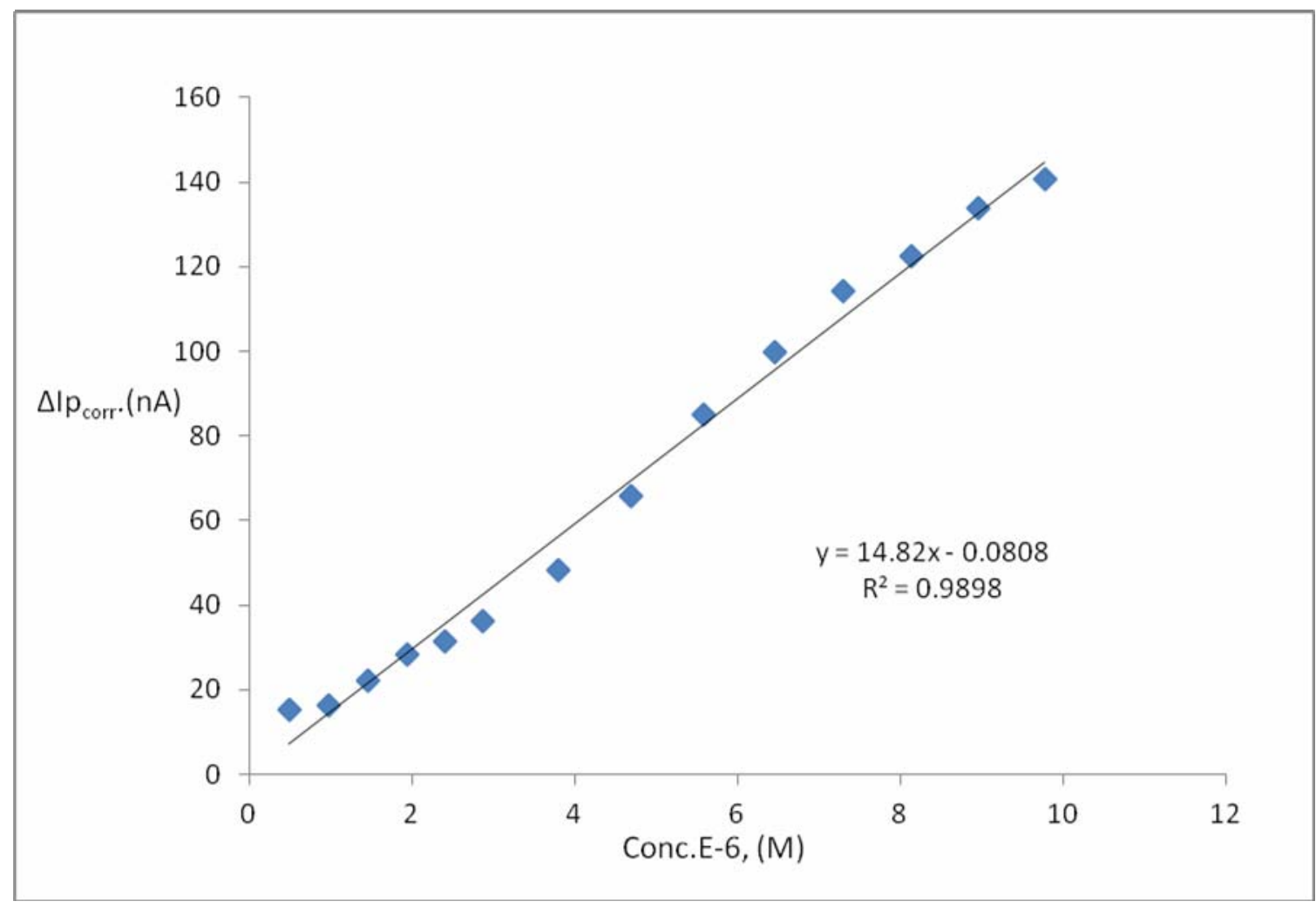

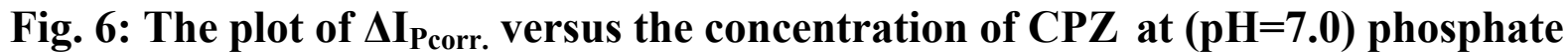
buffer 
Application of SWV of SNP to determine the concentration CPZ in tablet:

Using the optimum conditions in (Table 1), this method was successfully applied to determine the concentration of CPZ in tablets and to calculate the recovery of the drug. The results are tabulated in (Table 6).

Table 6 : The results of the CPZ in tablet

\begin{tabular}{|c|c|c|c|c|}
\hline Taken Conc. $(\mathbf{M}) \times \mathbf{1 0}^{-\mathbf{6}}$ & Found Conc. $(\mathbf{M}) \times \mathbf{1 0}^{-\mathbf{6}}$ & Recovery \% & Error & $\Delta \mathbf{I}_{\mathbf{p}}(\mathbf{n A})$ \\
\hline 1.932 & 1.917 & 99.212 & 0.787 & 12.60 \\
\hline 2.870 & 2.847 & 99.183 & 0.816 & 34.02 \\
\hline 5.140 & 5.105 & 99.330 & 0.669 & 72.66 \\
\hline 6.018 & 5.969 & 99.193 & 0.807 & 84.81 \\
\hline 8.144 & 8.264 & 101.466 & -1.466 & 104.51 \\
\hline 8.968 & 9.184 & 102.410 & -2.410 & 112.60 \\
\hline
\end{tabular}

\section{Comparison between the methods:}

A comparison between the present method and the British pharmacopoeia standard method (British Pharmacopoeia, 2007) for the determination of CPZ in tablets showed that there is an ability to use the present method to determine the concentration of CPZ in pharmaceutical preparation. The results are shown in (Table 7).

Table 7: Comparison between the present method and the British pharmacopoeia standard method

\begin{tabular}{|c|c|c|}
\hline Drug & \multicolumn{2}{|c|}{ Recovery \% } \\
\hline Largactil (50mg) (NDI) & Present method & $\begin{array}{c}\text { British pharmacopoeia } \\
\text { method }\end{array}$ \\
\cline { 2 - 3 } & 102.410 & 106.00 \\
\hline
\end{tabular}

\section{REFERENCES}

Butler, A.R.; Megson, I.L. (2002). Non-Heme iron nitrosyls in biology. Chem. Rev.102(4), 1155-1165.

Buttrefield, A.A.; Matsui, F.F.; Smith, S.J.; Sears, R.W. (1980). Rapid determination of chlorpromazine hydrochloride and two oxidation products in various pharmaceutical samples using high-performance liquid chromatography and fluorescence detection. J. Pharm. Sci., 66(5), 566-569.

Daniel, D.; Gutz, I.G. (2005). Spectroelectrochemical determination of chlorpromazine hydrochloride by flow-injection analysis. J. Pharm. Biomed. Anal., 37(2), 281-286.

Dermis, S.; Biryol, I. (1989). Voltammetric determination of chlorpromazine hydrochloride. Analyst, 114(4), 525-526.

Diaz, J. (1997). How drugs influence behavior: a neuro behavioral approach, Prentice Hall, N. J., 285.

Frag, E.Y.Z. ; Zayed, M.A. ; Omar, M.M.; Elashery, S.E.A.; Mohamed, G.G. (2012). Potentiometric determination of chlorpromazine $\mathrm{HCl}$ using carbon paste electrode in pure and pharmaceutical preparations. Int. J. Electrochem. Sci., 7, 650-662. 
Hammett, L.P. (1940). "Physical Organic Chemistry". McGraw-Hill, New York, pp. 184199.

Healy, D. (2004). "The Creation of Psychopharmacology". Harvard University press. pp. 37-73.

Li-tao, L.; Jing, L.; Guan-min, L.I. (2011). Spectrophotometric determination of chlorpromazine hydrochloride using potassium ferricyanide. Chinese. J. Anal. Lab.,30 (1).

Murakami, W.; Veno, T.; Hijikata, J.; Shirasawa, W. (1982). Simultaneous determination of chlorpromazine and levomepromazine in human plasma and urine. J. Chromatogr., 227(1), 103-112.

Ni, Y.; Wang, L.; Kokot, S. (2001). Voltummetric determination of chlorpromazine hydrochloride and promethazine hydrochloride with the use of multivariate calibration. Anal. Chim. Acta, 439, 159-168.

Rukhadze, M.D.; Okudzava, V.M.; Aleksishvill, M.M.; Tsagarell, S.K.; makharadze, T.G. (1999). Determination of chlorpromazine in blood serum by ion-pair reversed phase HPLC: chlorpromazine pharmacokinetics in rabbits. Pharm. Chem. J., 33(9), 41-43.

Stevenson, D.; Reid, E. (1981). Determination of chlorpromazine and its sulfoxide and 7hydroxy metabolites by ion-pair high pressure liquid Chromatography. Anal. Lett., 14(2), 1785-1805.

VijayRaju, G.; Jaffar, Sk.; Pal lavi priya, M.; Ibrahim, S.M.; Muralinath, E.; Guru Prasad, M. (2011). Application of $\mathrm{MBTH} / \mathrm{FeCl}_{3}$ : A reliable and cost effective analysis methodology for routine pharmaceutical determination of chlorpromazine hydrochloride, IJRRPAS,1(4), 202-206.

Willard, H.H.; Merrit, L.L.; Dean, J.A. (1974). "Instrumental Methods of Analysis". 5th ed., Litton Educational Publishing, Inc., New York, pp.237. 